\title{
UBUNTU - BEYOND BELIEF IN SOUTHERN AFRICA
}

\author{
Patrick McAllister
}

\begin{abstract}
The ideology of ubuntu (humane-ness) is currently widespread in Southern Africa, where it has experienced enormous growth since the demise of the apartheid state in South Africa in the early 1990s. In this paper the nature of the widespread belief in ubuntu as a principle guiding social action is examined, along with a variety of the ways in which it is manifested in public life. The claim that the contemporary manifestations of ubuntu are based on an indigenous African philosophy which informs action in daily life at the level of the village and kin group is then discussed and the evidence for such a claim examined. The positive as well as some of the potentially negative consequences of the belief in ubuntu are suggested.
\end{abstract}

\section{INTRODUCTION}

Ubuntu is a southern Bantu word meaning humanity, human nature, human kindness, or humane-ness. In sharing the root for 'person' (-ntu) it suggests 'personhood' in the abstract, the state of being a proper, moral, human being. In the Xhosa and Zulu languages, there are a number of words that share this root, including umntu, which means simply a person or a human being (plural abantu - people); also uluntu-mankind, commoners, and isintu, which means human ways, culture, humankind, or human language (Kropf 1915; Doke and Vilakazi 1972). Similar words, and with a similar range of meanings, exist in other Bantu languages throughout the sub-continent.

Some of these terms can be used synonymously with ubuntu. For example if one says of someone that he/she is 'truly a person' (ungumntu) it means that he/she is an upright, moral person, as when one says in Yiddish that someone is a Mensch! A rough equivalent in New Zealand or Australia would be to refer to someone (usually a man) as a 'good bugger'! 
In the last decade or so $u b u n t u$ has become a key notion in elite circles in South Africa, particularly, within the context of the demise of apartheid and the process of nation-building that followed. It has also spread more broadly than this so that it is now cited in almost any sphere of life. In this paper I outline some of its main manifestations, as a belief, ideal, and representation, and some of the various circumstances in which it is invoked. Secondly, I ask whether the belief in ubuntu as essentially African and associated with rural and kinship contexts, has any empirical basis.

Ubuntu's primary public profile is a key aspect of the notion of an 'African Renaissance', an ideal propagated by South Africa's President, Thabo Mbeki and by other leading southern African politicians, and it is an ideal that is often used in public life more generally. In this context ubuntu might be regarded as the most recent manifestation of the notion of an African humanism, similar to earlier notions such as ujamaa or negritude. Ubuntu has also been taken up by African intellectuals, philosophers and theologians, not without controversy (Ramose 2003). It has also been adopted in all sorts of other spheres, so that one now reads about $u b u n t u$ in the context of the law, the media, business management, African philosophy, theology, and so on (Boele van Hensbroek 2001).

Ubuntu is presented as a return to African roots and as essential to 'the African way of life'. It is believed to be based on a set of values and norms that define life in traditional extended family and village settings, and it is thus seen as an autochthonous cultural resource and an indigenous philosophy that can be used in modern southern Africa, that will help the region to take its place in the world. It assumes a basic continuity between past and present and the relevance of the former for the latter. It is viewed as the basis of an alternative modernity, vital for political and economic development and the construction of a contemporary African identity that contrasts with Western approaches and ideas, and which is thus also a gift to the world at large (Louw 2004; Van Binsbergen 2001; Malan 1995). It is the local which has become global.

The concept is linked with an oft cited Zulu-Xhosa aphorism, which again has counterparts in other languages such as SeSotho: umntu ngumntu ngabantu-'a person is a person through other people'. It thus references the social nature of personhood but posits this as uniquely African and contrasts it with Western individualism. Characteristics of $u b u n t u$ as a mode of conduct and a social ethic in contemporary life are said to be compassion for others, respect for difference and minority rights, an emphasis on reaching agreement and consensus, a spirit of mutual support and cooperation and associated traits such as hospitality, sharing, generosity, and selflessness (Battle 1998). 
South Africa's successful transition to a democratic state, including the process of reconciliation epitomised by the TRC (Truth and Reconciliation Commission), has been attributed partly to ubuntu. Indeed, the popularity of the notion owes much to Archbishop Desmond Tutu's use and explanation of the word:

When we want to give high praise to someone we say, 'Yu, unobuntu'; 'Hey, so-and-so has ubuntu.' Then you are generous, you are hospitable, you are friendly and caring and compassionate. You share what you have. It is to say, 'My humanity is caught up, is inextricably bound up, in what is yours.' ... A person with ubuntu is open and available to others, affirming of others, does not feel threatened that others are able and good, for he or she has a proper self-assurance that comes from knowing that he or she belongs in a greater whole and is diminished when others are humiliated or diminished, when others are tortured or oppressed.... To forgive is not just to be altruistic. It is the best form of self-interest. What dehumanizes you inexorably dehumanizes me. [Forgiveness] gives people resilience, enabling them to survive and emerge still human despite all efforts to dehumanize them. (Tutu 1999:34-35)

Tutu is said to have developed 'an ubuntu philosophy', which is a Christian theology that 'seeks to restore the oppressor's humanity by releasing and enabling the oppressed to see their oppressors as peers under God' (Stroble 1998). While theologians sing its praises and philosophers tease out its imagined nuances and implications, ubuntu has also been appropriated by sectors of the business community as a management strategy and embraced by many business organisations (Mbigi 1997), where it is construed as a particularly African management style that emphasises the importance of good communications, dialogue, and solidarity within organisations. Some local and international enterprises use the term in their name, seeking to apply in the business environment values and orientations which are assumed to exist in village life and which are thought to be uniquely African. For example, Ubuntu Linux is a distributor of the (free) Linux computer operating system which is said to be inspired by $u b u n t u$, arguing that it 'confers rights of software freedom' to the 'Ubuntu community' (Ubuntu n.d.).

Media academics have taken up the concept of ubuntu as a potential guiding principle and basis of media ethics (Blankenberg 1999; Christians 2004). Constitutional lawyers attempt to show how it is embodied in the South African constitution, even though the word is not defined there (Klug 2000). Other legal experts feel that it could become the basis of law in other spheres (Mokgoro 
1998). Development experts claim that the success or failure of development initiatives depends on the amount of ubuntu that is present (Rwelamila et al 1999). Politicians emphasise the need for ubuntu in making decisions and reaching consensus and lament the absence of ubuntu when trying to explain the very high rates of crime and violence in South Africa (Louw 2004). Some (such as Mbeki) see it as the path to the moral regeneration that is needed in the contemporary Southern African context (Dlamini 2006). A browse through the 95 million Google results for ' $u b u n t u$ ' indicates an extremely wide range of contexts in which the notion is being used-from urging compassion to AIDs sufferers ('Examples of ubuntu' n.d.) to the development of civic responsibility and the prevention of crime (Ubuntu Peace Project 2009); from creating effective management strategies to securing democracy and peace in Africa (Watkins 2005). Ubuntu, it seems, has become all things to all people, a magical elixir invoked to promote almost any form of human development, and to explain success and failure in many spheres of life.

It has been suggested that $u b u n t u$ enables cultural self-assertion and a pride in being African (Mbigi 1997). Some feel that it provides a set of guidelines or prescriptions that are necessary for South Africa's future development and that these are key elements of the 'African Renaissance' (Louw 2001). The sceptics and critics point out, however, that the term has been reified and credited with quasi-magical properties, fostering sweeping generalisations about the nature of African people and social relationships in Africa (Van Binsbergen 2001).

Does this mean that ubuntu is not 'authentic'? As soon as the question is posed in this way a host of problems arise. What does authenticity mean? How does one assess it? Authentic to whom? Is the question posed in the right way should it not be 'Is the belief in ubuntu authentic?' Since ubuntu is a representation, a discourse about human behaviour and morality, we have to answer this with a yes, it is real and authentic and it probably has real effects. It is a construction and as such is part of an identity-making process.

But is the belief mistaken, perhaps? In what sense? Is ubuntu really part of an essential African sociality? Do people relate to each other in rural, village contexts, in a manner consistent with the modern notion of $u b u n t u$ and knowing that they are acting in accordance with it? Here we are asking if ubuntu exists independently of its contemporary southern African representations in the many contexts in which, in terms of those representations, it is assumed to exist objectively. In other words, is ubuntu a characteristic of rural, village dwelling Africans? But which rural, village dwelling Africans are we talking about - all of them? At all times? Before this gets out of hand, let's simply ask 
whether there is any ethnographic evidence for the existence of ubuntu as a pervasive and systematic moral principle governing action in the southern African village settings studied by anthropologists and others and into which it has been projected by those espousing ubuntu in the modern, urban political context.

\section{THE VILLAGE SETTING}

The prominent Dutch anthropologist, Wim Van Binsbergen (2001), had claimed that there is no such ethnographic evidence. He has provided perhaps the most trenchant critique of the way in which ubuntu has been constructed and used in post-apartheid South Africa and beyond. He points out that it is an etic reconstruction, globalised in a form that bears little relation to any pre-existing traditional philosophy or the realities of village life in which it is presumed to originate. At best, in the life of the village ubuntu is an occasionally invoked concept which has meaning only in the particular context in which it is used. There are many other, in some ways similar but disconnected, terms that are used in daily life involving situations such as neighbourly cooperation, reaching consensus, respectful behaviour, and so on. Therefore one cannot describe the beliefs and values that affect ways of acting in the village or kin-group context as part of some coherent philosophy that can be subsumed under a single term or conceptual complex. And as in any social context, there are also beliefs and practices in the village that contradict the ideals ascribed by intellectuals to $u b u n t u$ but which are not discussed-such as conflict, violence, exploitation, greed, neglect, witchcraft accusations and sorcery.

In the context of rural African village life, such as that experienced and documented by anthropologists, the term ubuntu is but rarely heard, claims Van Binsbergen (2001), and I have to agree. In twenty four months of intermittent residence among Xhosa people in a rural location in Willowvale district, Transkei, I hardly ever heard the word, and I would not be able to produce evidence that it embodies a rural philosophy or set of values and norms that people use as an everyday reference to judge the quality of actions. This does not mean that it is non-existent-one hears it used from time to time. For example, on one occasion a man who had extended hospitality to visitors who were about to depart was told by a neighbour that this was a good thing that he had done, and that 'the day you refuse to accept visitors is the day you lose your ubuntu...' On another occasion, a beer drink ritual held to welcome a young migrant back from the mines, the migrant was told to be mindful of his senior kin, to identify with them and to take their advice, because 'a person's ubuntu is [how he relates to] his brother'. Note how these two examples are drawn from rather 
different spheres of activity, the one involving kinship obligations, the other hospitality towards visitors.

Generally speaking, however, the term ubuntu is rarely used in rural African villages, and there are a variety of other terms which evoke some of the qualities of rural life associated (in the modern usage) with ubuntu. The extensive co-operation and mutual support that exists between households in my research area is spoken of as 'good neighbourliness' (ubumelwane), 'mutual support' (ukuncedana), or 'mutual sympathy and understanding' (ukuvana), and it is underpinned by the important principle of reciprocity-people are expected to give something in return for assistance rendered, though the form that it takes may vary from labour equivalence to political support (McAllister 2001). Reciprocity is a basic principle of social interaction, encapsulated in the saying that 'one hand washes the other' (isandla sihlamba esinye), but this is not often recognised by the modern proponents of ubuntu, who tend to give the impression that it is based on total unselfishness and without expectation of any return. Rural Xhosa also speak of people's spirit (umphefumlo) in moral terms, or they use the image of the heart, as Westerners do, or the head, or the liver, for that matter, to make judgements about people's character (isimilo) and behaviour.

If one tries hard enough one can construct links between these concepts, to argue that they are all related under the rubric of African sociability, that they are backed by the ancestor cult and form a coherent framework for the conduct and evaluation of everyday life. I did so myself after my initial fieldwork spell, anxious to find order and system, and of course I found it, because I constructed it on the basis of interviews with people rather than on the basis of careful observation and recording. But in fact, I found later there is no coherent system, just an array of disconnected ideas and values that bear some similarities, that can be used in various ways in different situations, or that can all be used in relation to one particular situation.

However, I recognise that what I have been presenting as ethnographic evidence is my own particular representation of what village life during my fieldwork period was like, and that it may not always have been so. Historical analysis shows that good neighbourliness and the emphasis on reciprocity that accompanies it probably emerged as a specific organisational principle under conditions of radical and rapid social change during the first decades of colonisation of the Xhosa people by the British (McAllister 2005). So I cannot claim without qualification that my characterisation of social relations would hold good for all rural Xhosa people at all times. 
Van Binsbergen (2001), speaking as one who has both been recognised (by his village hosts) as a person (umntu) and denied such status by townspeople who reacted to him as a white stranger with a strange accent, acknowledges that $u b u n t u$ as used in contemporary Southern Africa is not meant to be a description of reality but is instead a utopian ideal which seeks to overcome the present condition, marked by various social ills of a national and global nature - crime, corruption, the problem of HIV/AIDS, and so on. Thus the recent xenophobic attacks by locals on foreign Africans was condemned as being contrary to the spirit of $u b u n t u$, which was required for the development of a humane and just society (News24 2008). These kinds of proclamations indicate that $u b u n t u$ as used in public life in southern Africa is the product of the local elite, operating in a modern, urban context and divorced from village life, which ignores history and change but systematises and articulates, in globalised format, a set of values and practices that at the grass roots level are largely intuitive and unsystematic.

In this sense $u b u n t u$ may well serve positive functions, as a form of symbolic empowerment that helps to create a positive self-image and an intellectual means to grapple with the world. As an ethical ideal, a concept that its proponents are attempting to revitalise, through redefining and reconstructing it, the notion of ubuntu provides an agenda, a possible way out of trouble, and a vision of the future. It usage creates a moral community, as Van Binsbergen (2001) points out, that shares this vision and a desire to overcome present problems, to transform apparently insurmountable difficulties into ones that can potentially be resolved.

Herein lie further possible dangers, however. An identity marker may be used to distinguish 'them' from 'us' and to essentialise and homogenise Africans, ignoring African diversity and promoting a superficial and erroneous stereotype. Simultaneously, it may act as a mechanism for defining the non-African 'other' as lacking in ubuntu. These claims are not the claims of a marginalised minority but the claims of the educated political and academic elite, who assume historical and spatial continuity, homogeneity, and African distinctiveness. In making the claim they seem unaware of the fact that they may be contributing to the development of a hegemonic and exclusivist ideology (Handler 2001). It is ironic that this could be happening in the shadow of apartheid.

Even when generalised to all South Africans irrespective of race, another possible difficulty arises, in that the ubuntu philosophy, with its emphasis on 
'agreeing to disagree', respecting difference, and appealing to a shared sociability and humanity in order to resolve conflicts and contradictions, suggests that there are no ways of really coming to grips with problems such as rampant crime, gender bias, class difference, historical inequalities, xenophobia, and the like. Many of the supposed characteristics of ubuntu, such as compromise and respect for difference, morph neatly into prescriptions for avoiding conflict in a divided society, not for resolving it. This may serve to protect the interests of the power elite, and to prevent resolution of real problems. The TRC itself was an example of this, says Van Binsbergen (2001), in its Christian emphasis on admission, apology and forgiveness rather than on redress (which would be important in the village). In this way ubuntu purports to be based on African values which are contradicted in practice.

\section{REFERENCES}

Battle, M. 1998 Reconciliation: The Ubuntu Theology of Desmond Tutu, New York: Pilgrim Press, The United Church Press.

Blankenberg, N. 1999 'In search of a real freedom: Ubuntu and the media', Critical Arts, 13(2): 42-65.

Boele van Hensbroek, P. (ed) 2001 African Renaissance and Ubuntu Philosophy, special issue of: Quest: An African Journal of Philosophy, 15(1-2).

Christians, C. G. 2004 'Ubuntu and communitarianism in media ethics', Ecquid Novi, 25(2): 235-256

Dlamini, N. 2006 'Mbeki: "Don't forget ubuntu"' http://www.southafrica.info/ services/government/mbeki_ubuntuo50506.htm

Doke, C. M. and Vilakazi, B.W. 1972 Zulu-English Dictionary (2 ${ }^{\text {nd }}$ edition), Johannesburg: Witwatersrand University Press.

'Examples of $u b u n t u$ ' n.d.. http://faculty.ccp.edu/faculty/jhoward/southafrica/ ubuntu.html

Handler, R. 2001 'Anthropology of authenticity', in International Encyclopaedia of Social and Behavioural Sciences, Elsevier Ltd: 963-967.

Klug, H. 2000 Constituting Democracy: Law, Globalism and South Africa's Political Reconstruction, Cambridge: Cambridge University Press. 
Kropf, A. 1915 A Kafir-English Dictionary (2 ${ }^{\text {nd }}$ edition), R. Godfrey (ed), Alice, Cape Province: Lovedale Press.

Louw, D. J. 2001 'Ubuntu and the challenges of multiculturalism in post-apartheid South Africa', in P. Boele van Hensbroek (ed), African Renaissance and Ubuntu Philosophy, special issue of Quest: An African Journal of Philosophy, 15(1-2): 15-36.

Louw, P. E. 2004 The Rise, Fall and Legacy of Apartheid, Westport, CT.: Greenwood Books.

Malan, M. 1995 'Leadership, integration and civic consciousness: From Innere Führung to Ubuntu', African Security Review, 4(3):16-24.

Mbigi, L. 1997 Ubuntu: The African Dream in Management, Randburg (South Africa): Knowledge Resources.

McAllister, P. A. 2001 Building the Homestead: Agriculture, Labour and Beer in South Africa'a Transkei, Aldershot: Ashgate.

McAllister P. A. 2005 Xhosa Beer Drinking Rituals: Power, Practice and Performance in the South African Rural Periphery, Durham, NC: Carolina Academic Press.

Mokgoro, Y. 1998 'Ubuntu and the law in South Africa', Buffalo Human Rights Law Review, 15:18-23.

News24, 2008 'It's an absolute disgrace - Mbeki', http://www.news24.com/ News24/South_Africa/Xenophobia/o,2-7-2382_2328907,oo.html

Ramose, M.B. 2003 'The philosophy of Ubuntu and Ubuntu as a philosophy', in P.H. Coetzee and A.P.J. Roux (eds) The African Philosophy Reader ( $2^{\text {nd }} \mathrm{ed}$.), New York/London: Routledge, 230-238.

Rwelamila, P. D., Talukhaba, A.A., and Ngowi, A.B. 1999 'Tracing the African project failure syndrome: The significance of "ubuntu", Engineering, Construction and Architectural Management, 6(4):335-346.

Stroble, P.E. 1998 'Reconciliation: The Ubuntu Theology of Desmond Tutu.' (Book review), Christian Century, http://www.michaelbattle.com/reconciliation. htm 
Tutu, D. 1999 No Future Without Forgiveness, New York: Doubleday.

Ubuntu n.d. 'Ubuntu Community: Our Philosophy' http://www.ubuntu.com/ community/ubuntustory/philosophy.

Ubuntu Peace Project, 2009 'Ubuntu Peace Project' http://www.ubuntupeaceproject.com/site/default.asp

Van Binsbergen, W. 2001 'Ubuntu and the Globalisation of Southern African Thought and Society', in P. Boele van Hensbroek (ed) African Renaissance and Ubuntu Philosophy, special issue of: Quest: An African Journal of Philosophy, 15(1-2): 53-89.

Watkins, R. 2005 'Ubuntu: African democracy in action.' http://www.izania.com/ forums/showthread.php?t=739 